\title{
Dukuhseti Women in a Negative Stigma Environment: Simone De Beauvoir's Existentialist Feminist Study
}

\author{
Laura Andri Retno Martini ${ }^{1 *}$ and Khotibul Umam $^{1}$ \\ ${ }^{1}$ Benaya Mahottama Sasalancana, Semarang, Indonesia \\ ${ }^{2}$ Faculty of Cultural Sciences, Diponegoro University, Semarang, Indonesia
}

\begin{abstract}
Dukuhseti is a sub-district located in Pati Regency, Central Java. This area is infamous for the dark history of prostitution that flourished in the 70 s. This condition still exists today, although not very much. The background and reasons why Dukuhseti women are involved in prostitution and the efforts they have made to get out of the "dark world" cannot erase the negative stigma that has developed in society. By using Simone De Beauvoir's study of the female existentialist, this study aims to describe the existence of women in Dukuhseti, Pati. This research is qualitative descriptive with research data obtained from interviews and FGD, as well as several supporting references and documentation. The results of the study generally show that the existence of Dukuhseti women in the fight against the negative stigma of society is still very far from Beauvoir's expectations. Even though some of them have managed to fight back and succeed by getting their freedom, most of them are still confined and unable to get out of this condition. To confirm their existence, Dukuhseti women must carry out transcendent processes, such as obtaining higher education, get work, being independent, and being actively involved in community activities.
\end{abstract}

\section{Background}

Prostitution is also called prostitution (from the Latin pro-stature or prostate) which means allowing oneself to commit adultery, prostitution, fornication, and concubines. Prostitution is a societal disease where a woman sells herself for a living. Society views negatively the activity of peddling sex because prostitution is against moral and religious values. No matter what people think about prostitution, in reality, this work has existed for hundreds of years, and no one has been able to erase it from the face of this earth [1].

Dukuhseti District is located in Pati Regency, Central Java. This area was chosen as the research location because it was in the dark history of prostitution in the 70s. The majority of the population of Dukuhseti Village work as farmers, farm labourers, entrepreneurs, brick makers, pond workers, and factory workers. The wages received as labourers are certainly very small. This resulted in the emergence of pockets of poverty in the village. Prostitution is one way of society to overcome poverty. Women work as prostitutes to earn a high income

* Corresponding author: lauraandri@,lecturer.undip.ac.id. 
compared to working as labourers. This condition continues until now, although the number is not as much as before. Dukuhseti women are closely related to prostitution. The background and reasons why Dukuhseti women engage in prostitution and the efforts they have made to get out of the black world cannot erase the negative stigma that has already developed in society.

In this study, the researcher used a qualitative descriptive research design, which is a study that produces descriptive data in both words and writing as well as observable behaviour of resource persons [2]. In addition, the research focus is directed at the existence of Dukuhseti women with an existentialist feminist review of Simone De Beauvoir. Women are present as second-class citizens, and their position is always subordinated. As a result of this inequality, feminism has emerged to fight for equality. According to existentialist feminists, human nature is freedom as much as possible.

By using Simone De Beavoir's existentialist feminism concept, researchers can see the existence of Dukuhseti women in the reality of their lives. If men have been the policymakers so far and all decisions are centred on men, then according to Beavior, women should be given the freedom to determine their own lives. The same freedoms were granted to men. Women have to work to be able to reclaim their transcendence. They must be able to become intellectuals by doing activities of thinking, observing, and identifying. In this case, women act as subjects and not objects identified. Women must take on a transforming role in society so that the role of women in social life becomes more recognized. In addition, women must also be independent, she rejects her otherness and unites herself through the views of the dominant group in society [3].

The theme of Dukuhseti women has been discussed in several studies, including Laura Andri Retno Martini. In the first study, the researcher described the social reality of the Dukuhseti community and literary works. How do authors who are part of society represent women in literary works? The prostitution that still exists in Dukuhseti Pati Village is also contained in the novel Genduk Dukuhseti. Sex and prostitution are ways that women use to represent their bodies.[4] In the second study, researchers analyzed the sea alms ceremony; a ritual activity carried out once a year by the people of Banyutowo. Banyutowo is one of the villages located in Dukuhseti District, Pati Regency. This traditional ceremony is performed every Sura month in the Javanese calendar. The sea alms have been going on for a long time and can become a strong cultural attraction. The meaning of sea alms for the coastal community of Banyutowo and cultural rituals is also a means of obtaining safety and maintaining the balance of nature. This ceremony has the aim of conveying gratitude for the sustenance given by God Almighty.[5]

This research took place in Dukuhseti Pati District, especially in Dukuhseti Village, Kembang, Banyutowo. The research location was chosen because this area has a long history of prostitution practices and is still ongoing today. In addition, prostitution does not only take place overseas but also in the form of local prostitution in the region.

\section{Method}

The method is a way of working to understand the object of research. This research is qualitative descriptive research with an analytical method. Qualitative research produces descriptive data in the form of written or spoken words and observable public behaviour. Qualitative research positions humans as objects to perform inductive data analysis and is more concerned with the process than the research results conducted and agreed upon by the researcher and the research object. The descriptive method examines the status of a human group, a subject, a set of conditions, a system of thought or a class of events in the present. The purpose of this descriptive research is to make a systematic description, picture or painting, and the relationship between the phenomena carried out.[6] The qualitative research 
method is a research method used to examine the condition of natural objects, where the researcher is the key instrument, sampling of data sources is carried out purposively and snowball, combining techniques with triangulation (combined), data analysis is inductive/qualitative, and research results more important than generalizations.[7]

Data collection techniques were carried out through in-depth interviews, observation, and documentation. In this regard, sources of information from books, papers, articles, and research results relevant to this study's topic will be used to sharpen the results of the study. This study also uses a snowball sampling technique due to the limited knowledge and information of the researcher about the research population. The researcher asks for help from key informants to show other people who can be used as further informants.

Observation is the collection of data that has specific characteristics when compared to interviews. If the interview is communicating with people, then the observation of other people's activities. In this observation, the researcher is actively involved in the daily activities of the person being observed or used as a source of research data.

\section{Result and Discussion}

In general, women are positioned as those supported by men, not to provide for men. Even if there are women who try to work outside the general provisions, the results of their work are only used for kitchen purposes, not for main purposes. In social life, this violates the existing stereotypes or can violate their nature as women.

Not only are that, but people's assumptions that women do not need to go to high school also growing. This assumption is reinforced because, in the end, women will only serve their husbands and children at home. Another reason that strengthens this assumption is that if women have higher education than men, it will be difficult to find a husband. The reason is that men will feel that women are more dominant than themselves.

From this, it can be interpreted that the position of women in this world is still under the control of men. They have no right in making decisions or steps in their lives, even though they are free to have so many desires. Whatever women do, they must have permission or approval from men. Even if they do this, the negative views and verbal abuse of the community are a risk.

\subsection{Women and Education}

From the data obtained in the field, the education level of Dukuhseti women is still relatively low. Some parents support their daughters in pursuing higher education, but most do not. This is due to the unavailability of education costs in the household, and also the public awareness of the importance of education for women is still very minimal. This is reinforced by the perception of the Dukuhseti community that women do not need to go to high school. This public perception is indicated by the assumption that in the end, women will only serve their husbands and children at home. Another reason that strengthens this perception is that it will be challenging to find a husband if women have higher education than men. The reason is that men will feel that women are more dominant or more dominant than themselves.

On average, Dukuhseti women can get the opportunity to continue their education to a higher level if they have obtained permission from their husbands, father, or brother. This means that women do not have full rights to make decisions for themselves. Women may have desires and will but do not have the power to decide what they want. Unlike men, they have full rights in making decisions in their lives.

Based on population data in the education sector in Kembang Village, Dukuhseti District, the number of people who do not go to school is $37.2 \%, 28 \%$ graduated from elementary school, 19.5\% graduated from junior high school, 12.4\% graduated from high school, and 
$2.6 \%$ passed PT. If seen from these data, it can be concluded that the community's level of education in Kembang village is very low. Even this data has not been divided between men and women. Data in the field shows that the education level of women is lower than that of men [8].

\subsection{Women and Their Role in Society}

\subsubsection{The role of women in village government}

Women's community organizations are listed in the institutional structure of the village government. Even special rules state that women must be represented in village institutional structures, such as BPD, LPMD. This means that women have an important role in supporting the running of the government in the village. However, the obstacle faced was that the village government did not listen to women's opinions, suggestions, and criticisms.

Women's voices are usually accommodated for activities related to women, such as PKK, Posyandu, sanitation, and environmental health issues. As for policies related to village development and running the wheels of government, the village government seems to 'forget' the voice of women. However, something is interesting in Dukuhseti. There are two villages where the position of village secretary is held by a woman, namely Dukuhseti and Kembang villages. The villages of Dukuhseti, Kembang, and Banyutowo both have two women who are village officials. It can be concluded that the representation of the number of women in village government institutions is sufficient, but the role of women in decision-making within the village government is still minimal..

\subsubsection{The role of women in socio-cultural activities}

In Dukuhseti, socio-cultural activities are more focused on religious activities. Women are active in religious activities, such as manaqiban, taklim assemblies, and so on. Community assistance activities that focus on issues of religion and religiosity are quite effective in reducing the number of prostitution in Dukuhseti. This assistance is carried out by mosques, church, and community leaders, both men and women. The role of women in reducing cases of prostitution is quite effective. The women included:

a. Siti Rufiah

He approaches prostitutes and their families as well as former prostitutes. He invites prostitutes and their families as well as former prostitutes to attend Idaroh tahlilan once a week. Idaroh is a collaborative activity to develop a business to achieve certain goals. Siti Rufiah also often gives alms to the underprivileged.

b. Mustafa and Muzaidah

The two men also carried out their da'wah strategy by giving alms. They also preach at recitation events, or training events, and routine gatherings. The da'wah material is also packaged attractively to reduce prostitution activities and prevent prostitution from spreading.

c. Siti Muthoharoh

Siti Muthoharoh has a unique way of reducing prostitution activities. In addition to providing spiritual guidance, she invites her closest neighbours or relatives to inflate the tires on the motorbikes/cars of mashers, set traps on the road, and scare the nosed men. the stripes [9]. 


\subsection{Independent Women}

In people who experience physical and psychological, which can lead to Stereotypes as negative labelling or marking of certain genders that result in discrimination and various injustices. The construction created by society positions women as an unchangeable essence [10]. The patriarchal culture in society constructs gender stereotypes of women as God's nature to be considered immutable.

In general, women are positioned as those supported by men, not to provide for men. Even if women try to work outside their domestic area, they will be considered as violating their nature or not according to existing stereotypes. The reason is that the general public considers women's work as filling their spare time to help their husbands and children or at least increase the cost for kitchen needs. If only women violated these rules, society would view this as wrong and underestimate it.

Consciously or not, women also imprison themselves in a patriarchal culture. When he was treated unfairly by his life partner, he did not dare to put up a fight. If they do this, it will be considered again against nature as a woman, and the worst possibility is that society will verbally abuse the woman. Therefore, accepting all forms of treatment for violence against him is a manifestation of maintaining that stereotype.

\subsection{Working Women}

On average, Dukuhseti women have a double workload. Apart from working in public areas, the burden of domestic work still has to be done. These domestic responsibilities are considered women's work. As a result, household chores, such as washing, cooking, caring for and taking care of children, cleaning and keeping the house tidy, and so on, are carried out by women. In addition, Dukuhseti women also have to work to meet the needs of their family life. In this case, women carry a double workload.

This double workload cannot be removed from the daily life of Dukuhseti women. Wives often receive violent treatment from their husbands. They must also be responsible for caring for and caring for their children and husbands and providing for the necessities of life for their family members. In addition, women also have to work as farm labourers and sometimes work as brick makers. All the responsibilities of family survival must be borne even though they should be shared with her husband.

One of the factors that make Dukuhseti women carry a double workload is poverty and lack of knowledge. Dukuhseti women live in these conditions. Regardless of their condition, the community environment that adheres to patriarchal understanding makes them not dare fight the injustice they experience. As a woman, living with a husband is better than living as a widow, even though she has to sacrifice her body and soul. This again raises the fact that gender differences will result in different treatments.

Based on the interviews, $75 \%$ of women in Dukuhseti who are involved in prostitution are still wives or housewives. Each of them has their reasons and backgrounds why they are involved in the world of prostitution. Their husbands ordered some; some were due to economic constraints, so women had to work to help their husbands meet the family's needs. In addition, the modelling factor is also a reason for women to engage in prostitution. Some women in Dukuhseti think that wealth and luxury are everything. Prostitution became a short way to accumulate wealth and luxury. Competition between them can be seen from the behaviour that wants to show off wealth. Looking at other female sex workers who are economically successful will become a model for other women. They will participate in prostitution because they think that being a commercial sex worker will make it easier to make money. They will soon be able to improve the family's economy [11]. When Dukuhseti women struggle to achieve a better life in terms of economy, their husbands are just the 
opposite. Based on the interviews, the male characters in the village are mostly lazy. They prefer to marry women and then be forced to become sex workers. The husband does not work but receives money from his wife.

\subsection{Dukuhseti Mythology as Legitimacy of Negative Stigma of Women}

The development of Dukuhseti as a coastal area has never been separated from cultural factors, both in patterns of behaviour, character, and daily living habits. The prostitution found in Dukuhseti Village has a close relationship with the folklore that developed and was recognized as true by the Dukuhseti community. According to the story of the Dukuhseti community, Brojoseti was the founder of Dukuhseti village and had a very beautiful wife. After several years of marriage, his wife had an affair and was caught red-handed by Brojoseti. Brojoseti was angry with his wife. Because his anger could not be contained, Brojoseti cursed his wife and all the village women who would always commit bad deeds. Some Dukuhseti people still believe in the curse. However, it could be that the story was deliberately presented as a justification for institutionalizing the culture of infidelity or even prostitution in Dukuhseti. Society has become very loose, as far as sex is concerned. For them, prostitution is already a destiny [12].

\section{Concusion}

The results of this study generally show that the existence of Dukuhseti women to fight the negative stigma of society is still very far from Beauvoir's expectations. Although some of them have succeeded in resisting and gaining their freedom, most are still trapped and have not been able to get out of this condition. To assert their existence, Dukuhseti women must carry out a process of transcendence, such as obtaining higher education, working, being independent and being actively involved in community activities. However, this will not be easy if the Dukuhseti community, in general, does not support this process.

\section{References}

1. D. Atmaja, Motivasi Dalam Berprotitusi Di Desa Dukuhseti Kabupaten Pati Jawa Tengah, Artikel dalam Web Psikologi dan Pendidikan edisi tanggal 10/01/2012 (2012). http://go2psychology.blogspot.com/2012/01/motivasi-dalam-berprotitusi-di-desa.html

2. L. J. Moleong, Metodologi Penelitian Kualitatif, Edisi Revisi. PT Remaja Rosdakarya Bandung , 6 (2007)

3. S. de. Second Sex: Fakta dan Mitos (Toni B Febrianto, Penerjemah), Narasi Yogyakarta (2016)

4. L. A. R. Martini, K.Umam, Dukuhseti Pati in Literature and Social Reality: A Perception About Women, in 5th International Conference on Energ, Environment, Epidemiology and Information System (2020)

5. L. A. R. Martini, R. Wulan, Meaning and Function of Sea Alms Ceremony for Coastal Communities Banyutowo Dukuhseti Pati, in 5th International Conference on Energy, Environment, Epidemiology and Information System (2020)

6. L. J. Moleong, Metodologi Penelitian Kualitatif Edisi Revisi, PT Remaja Rosdakarya Bandung (2007)

7. Sugiyono, Metode Penelitian Kombinasi (Mix Methods), Alfabeta Bandung (2015) 
8. Data monografi Desa Kembang Kecamatan Dukuheti Pati tahun 2018. http://kembangdukuhseti.desa.id/data-kependudukan/

9. W. Aulia, Dukuhseti: Dari Kampung Simpanan Menjadi Kampung Beriman, Kecamatan Dukuhseti, Kabupaten Pati, Tahun 1972-2016, Skripsi Program Studi Sejarah Peradaan Islam Fakultas Ushuluddin Adab Dan Humaniora Institut Agama Islam Negeri (IAIN) Salatiga (2020)

10. K. Syahrir, Kata Pengantarî dalam Negara dan Kekerasan Terhadap Perempuan, Subondo, Nur Iman (Ed.), Yayasan Jurnal Perempuan dan the Asia Foundation Indonesia Jakarta (2000)

11. Sahlan, Soebekti. 2017. Babad Desa Tulakan Kecamatan Donorojo Kabupaten Jepara. Tulisan pribadi

12. D. Atmaja, Motivasi Dalam Berprotitusi Di Desa Dukuhseti Kabupaten Pati Jawa Tengah, Artikel dalam Web Psikologi dan Pendidikan edisi tanggal 10/01/2012 (2012). http://go2psychology.blogspot.com/2012/01/motivasi-dalam-berprotitusi-di-desa.html 